\title{
Challenging Hierarchy: Narrative Ruminations on Leadership in Education
}

\author{
Carl Leggo
}

University of British Columbia

\begin{abstract}
Everybody involved in education is a potential educational leader. Consequently, leadership is everybody's responsibility, either in a designated role of leadership or in supporting those in formal positions of leadership. This essay invites readers to consider the value of telling stories about our lived experiences with educational leadership. We as educators need to learn how to engage in dialogue with one another, how to support one another, and how to live creatively with one another. We need new stories, more complex, intricate, and eloquent narratives that conceive, compose, and imagine our relationships with one another. We need new myths or at least we need to engage in a process of constantly reviewing and revising the myths that we live by. Our lives in schools and outside schools are located (called together) in stories. So, in this essay, I offer a few stories from a long life of teaching, stories that I anticipate might raise questions for educators about how we compose and sustain more creative relationships among all of us in our different roles. I focus on heart, humility, health, and hope as four familiar concepts in teaching and learning in order to contribute to a conversation that is ongoing, always in process, and never definitive. As educators, we need to communicate, respond to, evaluate, and transform our stories by infusing our pedagogy with heart, humility, health, and hope. Our stories shape our identities, compose our relationships, and create possibilities for learning to live well with one another.
\end{abstract}

Keywords: storytelling; narrative inquiry; educational leadership 


\title{
Challenging Hierarchy: Narrative Ruminations on Leadership in Education
}

\section{Pre-amble}

I begin this essay with something resembling a disclaimer: I am not a scholarly researcher with a focus on educational leadership, and I have never held a formal position of educational leadership. This essay invites readers to consider the value of telling stories about our lived experiences with educational leadership. I understand that the stories of educational leadership are complex and numerous. My first intention is to invite readers to consider how personal stories shape their understanding of educational leadership and their ways of responding to educational leaders. Like hooks (2003), I "rely on the sharing of personal narratives to remind folks that we are all struggling to raise our consciousness and figure out the best action to take" (p. 107). I have written extensively about narrative inquiry and life writing (Cohen, Porath, Clarke, Bai, Leggo, \& Meyer, 2012; Hasebe-Ludt, Chambers, \& Leggo, 2009; Hasebe-Ludt, Sinner, Leggo, Pletz, Simoongwe, \& Wilson, 2010; Kelly \& Leggo, 2008; Leggo, 2007a; Leggo, 2007b; Leggo, 2008; Leggo, 2010a; Leggo, 2010b; Leggo, 2010c; Leggo, 2011a; Leggo, 2011b; Meyer \& Leggo, 2009; Prendergast, Leggo, \& Sameshima, 2009; Sameshima \& Leggo, 2010). In much of that writing, my focus is on the discourse of narrative inquiry. I am particularly interested in attending to how stories are told and how the ways stories are told compose an understanding of experiences. So, this essay is not constructed like a traditional academic paper with an extensive literature review, a statement of a research question, and a structure that resembles a carefully designed urban subway system for carrying readers from one location to another. Rather, this essay is a walk on the beach, pausing occasionally to pick up a shell or stone, stopping sometimes to view the horizon, mostly meandering here and there, full of anticipation for surprises, content with what emerges on the journey. In other words, this essay attends to research as searching repeatedly.

Moreover, in the spirit of disclaiming, I must point out that regarding the stories included in this essay, the names of persons and schools are pseudonyms, and events are rendered as creative nonfiction or storytelling. It is doubtful that anyone would recognize their specific story in the stories I share. These stories are my self-narrated versions of events that took place, some, a long time ago. Historical veracity is not sought in these stories. I tell the stories as a part of my ongoing efforts to compose opportunities for inviting conversation. Consequently, I am not too interested in the empirical truth of the stories. Instead, I am eager to share the stories as representations of lived experiences that may evoke and provoke other stories, perhaps related and different, but definitely resonant.

\section{Amble}

I begin with a poem because poetry is really my first language, a kind of discourse that invites us to slow down and linger with stories, their rhythms, silence, and possibilities. Above all I am motivated by Baldwin's (2005) claim that "story is a search for community" (p. 224). I am always searching for community, always seeking opportunities for communing together, for telling stories that might transform our lives.

\section{Yo-Yo}

\author{
$I \&$ you \\ the two most used \\ words in English
}


full of Buber's

tensile tension

in Spanish

$I$ is yo

you is tú

I-you you-I I-I you-you yo-yo

yo-tú tú-yo yo-yo tú-tú I-I

I know you

you know me

the stranger within

the stranger without

all connected on a string

that knows the limits

of gravity, or at least

its seductive attraction

the constant challenge

of yo-yo tangles

common and idiosyncratic

DNA, in the mirror, the conjunction AND

everything, all of us entwined like vines.

I grew up in a working class home in a town that once boasted the world's biggest pulp and paper mill. My father was an electrician in that mill. As a boy, I quickly learned how industrial life is structured as a hierarchy made up of union employees, bosses, managers, and 
professionals. My father sometimes advised me, "Don't fraternize with the bosses!" (Etymologically, hierarchy is connected to Greek roots for the rule of a high priest.) Now as a middle-aged man, I still hold onto a working class boy's understanding of the world as structured hierarchically with class distinctions and roles based on a mixture of competition and grudging collaboration. Therefore, my vision of leadership in education has been indelibly marked by these lived experiences in a pulp and paper town. I was a secondary school teacher for 9 years in several small towns in Newfoundland, and I have been a professor of education at the University of British Columbia for 21 years. With the exception of a few summer jobs, I have always been a student or educator. My son and daughter attended schools in five provinces. My wife has been a kindergarten teacher and a classroom educational assistant for many years. Hence, I have a lot of experience with educational leadership. Nevertheless, much of that experience has not been very satisfying. In my lived experience, some school and university leaders were exemplary, but many more were not.

When I think about educational leaders, I often return to the synonym, administrator, which now seems less used than I remember. An administrator's professional role is a complex amalgam of seeming paradoxes. Administrators need to be firm and gentle, innocent and wise, and affectionate and impartial. Administer is from the Latin administrare, to serve. Yet, the definitions for the word administer seldom pay attention to the significance of the root to serve. Instead, to administer typically means to manage, conduct, direct, govern, or to give out or dispense or apply as punishment, justice or medicine.

I never aspired to a position of professional educational leadership, such as principal, department chair, or associate dean. Nonetheless, I am eager to be a strong supporter of others who are called to leadership. Too much of education has been represented in stories that construct dichotomies, such as leaders and followers, principals and teachers, deans and faculty members, or management and managed. King (2003) reminds us "to be careful with the stories," we tell and with the stories we are told (p. 10). He advises that if we want a different ethic, we need to "tell a different story" (p. 164). My goal in much of my narrative inquiry about education is to compose different stories, and hence different possibilities for understanding our lived experiences in education.

At 58 years of age, I am growing more conscious of how my sense of identity, of who I am, is constructed and constrained by a complex nexus of dynamics that include history, sociology, family, geography, ideology, and psychology. Consequently, my life and the stories that reveal an understanding of my life must be conscientiously and recursively reviewed. These life stories are an inextricable part of the curriculum and pedagogy that have shaped me. For all the privileges that I currently embody, my epistemologies as a university professor are imbued with working class values and ideals. Moreover, I am heterosexual, Christian, middle-aged, male, educated, economically advantaged, and physically able. "We are subject to discourse, not simply subjects through discourse with the ability to turn around, contemplate, and rework our subjectivity at will" (Hall, 2004, p. 127). So, we narrate ourselves and we are narrated by our lived experiences. Therefore, we are both the subjects and the predicates of the discursive functions that compose our subjectivity, which is always plural, multiple, tangled, mysterious, malleable, and unpredictable. We always occupy positions anchored to the pronoun $I$ with an abiding sense of individual autonomy and disposition as well as positions of relationship to all the other I's (generally perceived as a vast network of you's). Each of us chooses relationships and each of us is located in relationships, and all of us share experiences of common identities while also knowing ourselves as distinctive. As Salvio (2007) notes astutely, "the personal is already a plural condition" (p. 4). Self-identity is always inextricably connected to collective identity. Hall (2004) reminds us that "the question of agency, and our ability to act with intent and 
awareness, raises also the question of how we conceive of and define responsibility and culpability" (p. 125). I am especially interested in the questions of "responsibility and culpability. " I do not think most of us adequately recognize our responsibility to respond to one another with understanding. Too often, we are ready to perform the roles or identities that we assume have been assigned to us by ideological dynamics. Instead, we need to recognize how we are actively engaged in shaping and re-shaping our identities. As a boy growing up in a pulp and paper town with a distinct hierarchy constructed around a working class and a professional class, I learned early that some people are bosses and some people serve bosses. I understood that this kind of hierarchy set up relationships that were often dichotomous and conflictual. This kind of hierarchical relationship does not support effective and productive communication among leaders and followers. A more complex understanding of identities and relationships is needed.

In a typical school or university community, each person can name a list of subject positions he or she dwells in as descriptors or markers of identity, of belonging, of location. As people who are significantly invested in education, each of us often asks: What is my role? Perhaps we are so busy asking about our roles that we fail to consider how we can use our gifts to help create the community. We each represent multiple subjectivities that we live with always, but generally conceal behind the predictable guises of our public persona. We are many people, and we need to celebrate the diversity that inevitably characterizes human beings who are always becoming, constituted in the play of language. We all need to commit ourselves to writing and re-writing our stories together.

Consider the complexity of the educational enterprise. The key players include: accountants, administrators, adults, advisors, advocates, artists, assistants, authors, bus drivers, businesses, carpenters, children, coaches, consultants, counsellors, curriculum specialists, custodians, dieticians, electricians, fathers, food providers, grandparents, helpers, historians, individuals, intellectuals, journalists, keepers, leaders, mothers, neighbours, office staff, poets, professors, psychologists, quizmasters, researchers, secretaries, scholars, students, superintendents, teachers, technicians, teens, therapists, urchins, veterans, volunteers, voters, wisdom-seekers, xylophonists, youth, zealots. There are so many participants in any educational community. In order for an education community to succeed, everybody involved must be responsible for one another, and must be committed to responding to one another.

While it is never easy to sort out the complex interrelationships of roles and responsibilities different participants represent and perform in an educational system, leadership is everybody's responsibility, either in a designated role of leadership or in supporting those in formal positions of leadership. Therefore, we need to consider that responsibility in thoughtful, insightful, and effective ways. We need to ask questions such as: Who leads? Are leaders failing to lead well because nobody knows how to relate to one another? Are leaders unable to lead because their energies and time are consumed with multiple tasks that go beyond their responsibilities? In Failing Our Kids: How We Are Ruining Our Public Schools, Ungerleider (2003) is concerned that school leaders "are too easily distracted from the central work of public schooling" (p. 222). He is concerned that school leaders cannot provide leadership because they are constantly distracted by diverse tasks that preoccupy them and "turn them from leaders into managers" (p. 223). It is always imperative to remember how messy is the experience of education.

In effect, educators live in an ecotone. Ecologists describe the place where two ecological habitats such as a forest and a meadow intersect as an ecotone, a place of tension (from oikos or habitation, and tonos or tension). The ecotone is a place where two habitats 
meet and overlap, where they extend into one another and create a place of fecundity that is only possible because of the overlapping. In other words, the ecotone is a space of productive tension where life can be more complex and intense than in either of the distinct habitats.

In the world of schooling, we are all in balance, much like a mobile or a poem or a community. In Teaching Community: A Pedagogy of Hope, hooks (2003) claims that "a culture of domination, like ours, does not strive to teach us how to live in community" (p. 163). She argues compellingly that if we are going to learn how "to live in community with all life" then we must "be guided by love" (p. 163). Therefore, we need to find "out what connects us, revelling in our differences" (p. 197).

In a similar way, Palmer (2004) understands that "a community is a chaotic, emergent, and creative force field that needs constant tending" (p. 76). He understands how any community involves a circle of trust that "honors both our differences and our connections" (p. 127). Palmer asks: "What do we do in a circle of trust?...[W]e speak our own truth; we listen receptively to the truth of others" (p. 116). For Palmer, truth telling is best sustained in storytelling. He is concerned that "instead of telling our vulnerable stories, we seek safety in abstractions, speaking to each other about our opinions, ideas, and beliefs rather than about our lives" (p. 123). Then, "as our discourse becomes more abstract, the less connected we feel" (p. 123).

And in related ways, Hanh (2003) understands that "we all live and function within different kinds of communities" and that participants in a community need to practice with care and commitment effective strategies for communication and supporting one another (p. 5). Hanh understands that a community emerges from frank conversation that includes criticism and truth telling. I do not share critical stories in order to complain and point fingers of accusation at others, but I am committed to the need to investigate and interrogate the complex stories that shape our lives as educators. Like McCourt (2005), I claim "storytelling is teaching" (p. 26). A parent told McCourt early in his teaching career: "Stick to the spelling and the words ..., and the parents of this school will thank you forever. Forget the storytelling. If we want stories we got a TV Guide and the Reader's Digest at home" (p. 75). A colleague who once reviewed my teaching as part of the promotion process complimented me profusely but was still concerned that I told too many stories. I am still telling stories -- lots of them!

Educational leadership needs to be fostered by human and humane qualities and experiences. Berry (1990) observes that "most of us no longer talk with each other, much less tell each other stories" (p. 159). Everybody involved in education is a potential educational leader. Therefore, leadership is everybody's responsibility. We need to learn how to engage in dialogue with one another, how to support one another, how to live creatively with one another. We need new stories, more complex and intricate and eloquent narratives that conceive, compose, and imagine our relationships with one another. We need new myths or at least we need to engage in a process of constantly reviewing and revising the myths that we live by. Our lives in schools and outside schools are located (called together) in stories. So, in this essay, I offer a few stories from a long life of teaching, stories that I anticipate might raise questions for educators about how we compose and sustain more creative relationships among all of us in our different roles. I focus on heart, humility, health, and hope as four familiar concepts in teaching and learning in order to contribute to a conversation that is ongoing, always in process, and never definitive. As educators, we need to communicate, respond to, evaluate, and transform our stories by infusing our pedagogy with heart, humility, health, and hope. Our stories shape our identities, compose our relationships, and create possibilities for learning to live well with one another. 


\section{A Pedagogy of Heart}

We have disregarded the heart, seeing it only as a symbol of weakness, the centre of sentimentality and emotion, instead of as a powerhouse of love that can reorient us from our self-centredness, revealing to us and to others the basic beauty of humanity, empowering us to grow. (Vanier, 1998, p. 78)

I began my first teaching position in 1976 at a high school in Morrow's Cove in the northwest corner of Newfoundland. At 22 years old, I was young, enthusiastic, and committed to being the best teacher I could be. The principal of Milley Collegiate was a middle-aged man named Wilfred who clearly liked being an administrator much more than the teachers on his staff liked his administration. My first teaching assignment was as a classroom teacher for Grade 7. Just months before, I went to Morrow's Cove, the school board had made a decision that Grade 7 would be taught by one homeroom teacher who would have responsibility for teaching all subjects. The plan was to create a sense of stability and order and community in the Grade 7 class by keeping everybody together through the year. I agreed that the plan was a promising one, and I was anticipating eagerly being part of the adventure. However, on the first day of school the enrolment in my Grade 7 class was 48 students. Though the school was located in a small town with a 1000 people, the school also served as the high school for several elementary schools in towns around the bay. Students were bused to Milley Collegiate. Many of them were bused to Grade 7. By the time students reached senior high school, many had already quit, and so the Grade 12 class had 12 students. I assume that Wilfred knew that the Grade 7 class was going to be very big. In addition to being the principal of Milley Collegiate, he was also called a co-ordinating principal with responsibility for overseeing the principals of the four elementary schools whose students attended Milley Collegiate. He would have known in June how many students would be attending Grade 7 at Milley Collegiate. However, on the first day of school when the 48 students squeezed into the Grade 7 classroom, located on the second floor of the school building, separated by a stairwell and the lobby and a hallway from the rest of the high school, Wilfred looked very surprised by how many students had actually turned up. I could see in his face a look that said, What in the world do I do now? The entire population of the high school for the year was 132 students in five classrooms. I was responsible for 48 of the students, more than a third, while most other teachers had classes of 12, 16, and 21 students. (The Grade 8 teacher, also a new teacher, had 35 students.) Wilfred's solution to the large number of Grade 7 students was to locate sufficient seats for my room. Designed for about 30 students, the room soon felt like a crowded subway train. I will leave to your imagination the stories that my 48 students and I lived together that year.

Wilfred was not concerned about my students or me. Instead, he was more concerned about order, having enough seats for all the students, about managing the timetable and the school bells and discipline. Wilfred was a friendly man. He was committed to professional development. Moreover, he was pursuing graduate studies in educational administration. He smiled a great deal as he passed through the staff room on his way to the staff washroom. However, as a school principal he lived in fearful anticipation of the problems, dilemmas, and catastrophes always lurking around the corner. He sought the simplest solutions to all problems, dilemmas, and catastrophes (which usually meant ignoring them). What would Wilfred's leadership have been like if he had acknowledged the heart as "a powerhouse of love" that enthused and energized all his encounters and decision-making with students, teachers, and parents? When Arrien (2005) asks, "Who have been the teachers of our hearts? What are we learning about love? What do we know about love?" (p. 92), I recognize that a pedagogy of the heart is the foundation for all other learning and living and leading. 


\section{A Pedagogy of Humility}

Reverence and a keen eye for the ridiculous are allies: both keep people from being pompous or stuck up. (Woodruff, 2001, p. 5)

For 6 years, I taught at another school in another small Newfoundland town with another principal who had a graduate degree in educational administration. He and Wilfred could have been brothers. Fred did not smile as much as Wilfred. Nonetheless, he approached life in much the same way. The school was like a complicated machine that had to be coordinated and fuelled, oiled, and timed in order that the parts could function. There was a sense that planning and organization were all that was needed for the effective operation of a school. Fred would not allow the eight teachers on the staff to have a master key that would give them access to the different rooms of the school like the laboratory, gymnasium, library, and cafeteria. He claimed that the teachers would mislay and lose the keys, and that students might find them and break into places they were not permitted. So, in the staffroom there was a key-board where keys for the rooms were pinned and labeled. Because the teachers had a way of sticking the keys in their pockets and forgetting to return them to the keyboard, Fred tied large objects to the ends of the keys; for example, a 12-inch ruler, a wrench, a portion of green garden hose. Teachers still sometimes mislaid the keys or poked them in their briefcases or even pockets. I frequently had to ask Fred if I could borrow his master key because students were either waiting for me to get the floor hockey equipment or were milling around outside the library door. Sometimes I asked for my own master key. Often I grew angry. While I was supervising during lunch break, I had to climb over a seven-foot barrier, then drop down into a storage room in order to get a bucket and mop to clean up after a student threw up in the hallway. Sometimes I reasoned with Fred. More often, I pleaded. And on occasion, I even glowered. But, of course, nothing I did convinced Fred to acquiesce. This was the most frustrating lesson I learned about Fred. He never changed his mind. He had what seemed to be a boundless confidence in his decisions.

The administrator is a servant or steward because he or she is entrusted with the responsibility to manage faithfully and effectively the resources of others, including human resources and material resources. Consider the reputation of the administrator. Should an administrator be given respect by virtue of his or her position? Or should the respect only be given when deserved or warranted? As a steward, an administrator is given trust because he or she has demonstrated trustworthiness. People depend on the steward. I wonder if we have diminished the significance of the word administrator by ignoring the notion of serving one's community. Do we perceive the administrator as a lord or a ruler? Is there an attitude among teachers of us and them? Is there a similar attitude among students and administrators? Instead, how might we re-imagine the administrator's role in education? Isn't the administrator serving teachers, students, parents, the school board, and the custodial and secretarial staffs? Isn't the administrator like the host of a party, a kind of matchmaker, a builder of bridges among the diverse constituencies of the school community? To understand the educational leader as an administrator who serves others is to re-envision authority as integrally connected to humility. But authority and humility are generally construed as antonyms. Administrators who understand the role of stewardship will know they are entrusted with the necessary wisdom to supervise responsibly and manage faithfully. They know about being trusted, as well as about trusting others. The steward serves others; the steward allows others to serve others; the steward invites being served by others. A pedagogy of humility keeps us sturdily located in the earth. 


\section{A Pedagogy of Health}

Unarticulated experiences that are not allowed into the story can show up years later as trauma, disease, mental illness, or a midlife crisis. But when these same experiences are shifted into language and successfully worked through in the healing power of story, they lay the groundwork for transformative personal development. (Baldwin, 2005, pp. 82-83)

Some years ago, I heard an educational leader boasting that his faculty members always worked hard, at least 60 hours per week. I wanted to interject with a word of caution that 60 hours per week was perhaps too much. Instead, I remained silent. I am often silent in situations where I think that my voice is not so much countercultural as simply contrary. I recall several times how both my parents frequently complained that I whined too much, that I was a whiner. I don't remember ever thinking that their judgment was fair. Nonetheless, I learned early that complaining and criticizing can invite a lot of complaints and criticism. Mostly, I learned at an early age to live in fear of speaking my mind or telling the truth. Here, hooks (2003) remind us "conversation is the central location of pedagogy for the democratic educator" (p. 44). I am still learning how to speak with sufficient courage.

When the educational leader boasted about his faculty members working hard, I wish I had cited Tomlinson's (2007) thesis that we live in "a culture of instantaneity -- a culture accustomed to rapid delivery, ubiquitous availability and the instant gratification of desires" (p. 74), and this culture is underpinned by "an economy and an associated work culture geared not just to sustaining but to constantly increasing this tempo of life" (p. 74). I wish I had spoken up about "the restlessness that is inherent in desire" (Tomlinson, 2007, p. 140), and promoted Tomlinson's advice about seeking balance in our lives. Tomlinson does not promote a simplistic notion of balance as "finding a sense of personal equilibrium within the disorienting hurry of life, of locating one's emotional and experiential 'centre"' (p. 153). Instead, Tomlinson argues that finding balance "implies the reflexive monitoring of practices and experience" (p. 153) especially by "assuming an ongoing control of one's life by choosing and deciding what is appropriate, what is sufficient, what is excessive, and acting to achieve these ends" (p. 153).

The best way for educators to foster health is to learn to tell our stories and to learn to listen to the stories of others. I take Baldwin's (2005) claim quite literally: "[S]tory heals" (p. 42). By telling our stories, we can know our connections to others and we can learn to lean on one another in a pedagogy of health.

\section{A Pedagogy of Hope}

To successfully do the work of unlearning domination, a democratic educator has to cultivate a spirit of hopefulness about the capacity of individuals to change. (hooks, 2003, p. 73)

In my final year of school teaching, I met an administrator who exemplifies for me the qualities I most admire in a principal. Liam was trusted by the teachers, and in turn, he trusted the teachers. He knew how to delegate authority. He respected the teachers. Liam organized a 2-day autumn retreat for the staff, an opportunity to gather at a rustic lodge on Deer Lake, where we could collectively talk about our conceptions for an effective school. More importantly, we were invited to dream possibilities for serving our school community for the future. Liam proposed that we concentrate on what we would like to develop in our school. He accentuated the positive. Don't say things like: Oh, we don't have the money for that. Oh, that won't work with my students. That's way too idealistic! He told us to dream. And we did. The discussions were invigorating. As a teacher, I was encouraged that my opinions and views were important. The principal recognized that the teachers were significant in his school. What were the characteristics we wanted in an effective school? What did we need to 
do in order to accomplish our goals? Some teachers whined with weary pessimism. Nonetheless, most of us were inspired by Liam's example to talk frankly and openly as we regained a sense of vision for our participation in a school community.

Here the administrator is a herald. With indefatigable spirit and zeal, he or she proclaims the good news that education is a significant enterprise. The effective administrator fires the hearts and the imaginations of teachers and parents and students, not with platitudes and shopworn homilies that nobody believes, but with the model of a life committed to learning and teaching, to risk-taking and experimentation, to journeying and growing. Being an administrator is a way of life, the living out of a vocation or calling, a way of dwelling in the world. The administrator is a visionary whose feet are firm and steady in the soil (even mud) of real lived experience with all the constraints imposed by time and money and differences of opinion, while at the same time dreaming new possibilities. Administrators need to investigate their hearts often, and to nurture their hearts with warmth, intimacy, and spontaneity. Being an administrator is a way of living, and the most successful administrators will be those who live close to the heart and imagination. However, so many administrators I have known have been caught up in a riot of damage control, seeking to cover up and conceal the conflicts and rifts and failures. What would happen if administrators sought to tell the stories of school with candour and truth? The administrator has authority, but this authority can be the privilege to author, to write the stories, as they have not been written. Brueggemann (2001) understands that "speech about hope cannot be explanatory and scientifically argumentative; rather, it must be lyrical in the sense that it touches the hopeless person at many different points" (p. 65). How does a leader sustain hope? Brueggemann (2001) reminds us that "questions of implementation are of no consequence until the vision can be imagined. The imagination must come before the implementation" (p. 40). How can leaders nurture and sustain imagination in the midst of an i-centered culture with tight-fisted fiscal constraints and fundamentalist frenzy? How can leaders foster hope in a culture that is focused on accountability, control, and judgement? These are the kinds of questions that we need to ask, frequently, questions that can be addressed in stories, as we pursue a pedagogy of hope.

\section{Still Ambling}

While I acknowledge the distinction between personal and professional relationships, I eagerly contend that the personal cannot be divorced from the professional. Human relationships ought to be humane. As a teacher, I depended on the principal to guide me, support me, and encourage me; as a professor, I depend on the dean, the associate deans, and the department head to administer with wisdom and care and courage. Administrators need to love the people they seek to administer. Consequently, they need to know the people they administer. They need to enter imaginatively into the lived experiences of others. They need to listen to others. They need to learn from others. They need to listen to the stories of others. It is not enough to know how to manage timetabling or prepare a budget, or organize an office. Administrators need to hear the stories of others so that they know the others they are serving. There is too much brusque, matter-of-fact, get-it-done, organized, armor-clad, technocratic attitude among administrators. They need to be gentle, hopeful, tender, and intimate. Woodruff (2001) explains how "the power of leaders derives from character, and their authority is essentially moral" (p. 114). For Woodruff (2001), "reverence is the virtue that keeps leaders from trying to take tight control of other people's lives. Simply put, reverence is the virtue that keeps human beings from trying to act like gods" (p. 4). Administrators must avoid sourness, disappointment, frustration, loss of hope, bitterness, and sarcasm. Like a good poet, the administrator fills people with courage, hope, and resolve to live in the now, to live each day with purpose. 
In my lifetime, as a teacher and professor, I have experienced many educational leaders. They were all good managers who knew how to keep the complex mechanism of a school or university unit running with apparent smoothness, but the most effective leaders also recognized that educational communities are more like an organism than a mechanism, living communities of human beings who need more than good management. Above all, educational communities need leaders and participants who are devoted to living with heart, humility, health, and hope. As I draw to a temporary conclusion, I acknowledge that this essay is just one more attempt to invite conversation. I have told some stories, ruminated on some scholarly literature, and raised some questions. As a teacher, that is what I have done for a long time. And as a poet, I call out a final poem, always filled with an eagerness for connection. I draw to a temporary close with a poem because a poem often breathes with the heart's rhythms, and acknowledges earthy roots, and seeks health in a hopeful spirit.

\section{Commute}

I want to stick my head

out the car window and sing,

I love you, to everybody I see,

but the wind whips my words.

I want to dance a loose-limbed frolic

in the triangle where highways meet

and grass juts out of the cement, but

I need somebody to teach me to dance.

I want to ring cell phones

and analyze the textual significance

of bumper stickers with other drivers,

but I don't have a cell phone.

I want to make paper planes

and write messages on the wings,

but I was a good kid in school.

I don't know how to make paper planes.

I want to compose music for car horns,

Bach's "Jesu, Joy of Man's Desiring"

etched in the sky, but I can't

tell a sharp C from C-plus. 
I want to grin at people in cars,

but they'll think I'm the village idiot,

and I am, but they won't be amused,

so I will continue my commute.

Will anyone commute my sentence, even this sad sentence I am writing? 


\section{References}

Arrien, A. (2005). The second half of life: Opening the eight gates of wisdom. Boulder: Sounds True.

Baldwin, C. (2005). Storycatcher: Making sense of our lives through the power and practice of story. Novato: New World Library.

Berry, W. (1990). What are people for?: Essays. New York: North Point Press.

Brueggemann, W. (2001). The prophetic imagination. Minneapolis: Fortress Press.

Cohen, A., Porath, M., Clarke, A., Bai, H., Leggo, C., \& Meyer, K. (2012). Speaking of teaching: Inclinations, inspirations, and innerworkings. Rotterdam: Sense Publishers.

Hall, D. E. (2004). Subjectivity. New York: Routledge.

Hanh, T. N. (2003). Joyfully together: The art of building a harmonious community. Berkeley: Parallax Press.

Hasebe-Ludt, E., Chambers, C., \& Leggo, C. (2009). Life Writing and Literary Métissage as an Ethos for Our Times. New York: Peter Lang.

Hasebe-Ludt, E., Sinner, A., Leggo, C., Pletz, J., Simoongwe, F., \& Wilson, L. (2010). These tensioned places of teaching: Life writing in precarious cosmopolitan times. Creative Approaches to Research, 3(2), 21-38.

hooks, b. (2003). Teaching community: A pedagogy of hope. New York: Routledge.

Kelly, R., \& Leggo, C. (Eds.). (2008). Creative expression, creative education. Calgary: Detselig.

King, T. (2003). The truth about stories: A native narrative. Toronto: House of Anansi Press.

Leggo, C. (2007a). Tangled lines: The art of researching our lives. The Journal of Educational Thought, 41(2), 191-199.

Leggo, C. (2007b). Writing truth in classrooms: Personal revelation and pedagogy. International Journal of Whole Schooling, 3(1), 27-37.

Leggo, C. (2008). Narrative inquiry: Attending to the art of discourse. Language \& Literacy, 10(1), 21. Retrieve from: http://www.langandlit.ualberta.ca/current.html

Leggo, C. (2010a). Writing a life: Representation in language and image. Transnational Curriculum Inquiry, 7(2), 47-61.

Leggo, C. (2010b). Lifewriting: A poet's cautionary tale. LEARNing Landscapes, 4(1), 67-84.

Leggo, C. (2010c). Writing a life: Representation in language and image. Transnational Curriculum Inquiry, 7(2), 47-61.

Leggo, C. (2011a). Living love: Confessions of a fearful teacher. JCACS (Journal of the Canadian Association of Curriculum Studies), 9(1), 115-144.

Leggo, C. (2011b). A heartful pedagogy of care: A grandfather's perambulations. In J. A. Kentel (Ed.), Educating the young: The ethics of care (pp. 61-83). New York: Peter Lang.

McCourt, F. (2005). Teacher man: A memoir. New York: Scribner. 
Meyer, K., \& Leggo, C. (2009). Imagining otherwise: Tantalizing tales from the Centre. In P. Lewis \& J. Tupper (Eds.), Challenges bequeathed: Taking up the challenges of Dwayne Huebner (pp. 39-50). Rotterdam: Sense Publishers.

Palmer, P. J. (2004). A hidden wholeness: The journey toward an undivided life. San Francisco: Jossey-Bass.

Prendergast, M., Leggo, C., \& Sameshima, P. (Eds.). (2009). Poetic inquiry: Vibrant voices in the social sciences. Rotterdam: Sense Publishers.

Salvio, P. M. (2007). Anne Sexton: Teacher of weird abundance. Albany: State University of New York Press.

Sameshima, P., \& Leggo, C. (2010). The poet's corpus in love: Passionate pedagogy. Journal of Curriculum Theorizing, 26(1), 65-81.

Tomlinson, J. (2007). The culture of speed: The coming of immediacy. London: SAGE.

Ungerleider, C. (2003). Failing our kids: How we are ruining our public schools. Toronto: McClelland \& Stewart.

Vanier, J. (1998). Becoming human. Toronto: House of Anansi Press.

Woodruff, P. (2001). Reverence: Renewing a forgotten virtue. Oxford: Oxford University Press. 